\title{
Differences in the whistle characteristics and repertoire of Bottlenose and Spinner Dolphins
}

\author{
CARMEN BAZÚA-DURÁN \\ Laboratorio de Acústica Aplicada y Vibraciones, CCADET, UNAM, Cd. Universitaria A.P. 70-186 \\ 04510 México, D.F., México
}

Manuscript received on January 15, 2004; accepted for publication on February 5, 2004.

\begin{abstract}
Several methods have been used to compare the whistles produced by dolphins. The two methods used in this study are: (1) a classification of whistle contours in six categories (i.e. constant frequency, upsweep, downsweep, concave, convex, and sine) and (2) the extraction of frequency and time parameters from each whistle contour. Bottlenose Dolphin Tursiops truncatus whistles are described in the same way when comparing whistle contour distributions in each of the six categories and whistle frequency and time parameters using Discriminant Function Analysis. For Spinner Dolphin Stenella longirostris whistles, each method describes whistles differently. Several facts may explain these differences in describing dolphin whistles, such as a greater fluidity of Spinner Dolphin groups when compared to Bottlenose Dolphin groups, greater geographic variation in the whistles of Bottlenose Dolphins than in those of Spinner Dolphins, an average beginning frequency $16 \%$ lower than the average ending frequency in Spinner Dolphin whistles compared to a varied relationship for Bottlenose Dolphins, and stricter criteria used to define whistle contour categories in the study of Spinner Dolphin whistles than in the Bottlenose Dolphin whistle study.
\end{abstract}

Key words: whistle characteristics, classification methods, whistle comparison, geographic variations, Delphinidae.

\section{INTRODUCTION}

Bottlenose Tursiops truncatus and Spinner Stenella longirostris Dolphins live in fission-fusion societies in coastal and oceanic waters of the world's oceans (Norris et al. 1994, Wells and Scott 2002). Bottlenose Dolphins inhabit tropical and temperate zones $\left(60^{\circ} \mathrm{N}-50^{\circ} \mathrm{S}\right)$ with herd sizes that range from 1 to 30 animals in coastal areas and up to hundreds in oceanic waters (Jefferson et al. 1993). Spinner Dolphins inhabit tropical and subtropical zones $\left(40^{\circ} \mathrm{N}-30^{\circ} \mathrm{S}\right)$ (Jefferson et al. 1993) with herd sizes that range from 2 to 300 in coastal areas (Bazúa Durán 2001) and up to thousands in oceanic wa-

E-mail: bazua@servidor.unam.mx ters (Scott and Cattanach 1998). Spinner Dolphins rest and socialize during the day, feeding at night on mesopelagic prey (Norris et al. 1994), while Bottlenose Dolphins rest, socialize, and feed both during the day and night (Wells and Scott 2002).

Bottlenose and Spinner Dolphin acoustic emissions or phonations can be classified into two general categories: a) tonal whistles, and b) pulsed sounds or clicks (Herman and Tavolga 1980). Dolphin whistles have typically been characterized in terms of their frequency as a function of time (spectrograms) (see Fig. 1), which is also referred to as "whistle contour" (Dreher 1961). Whistles are frequencymodulated sounds with a fundamental frequency 


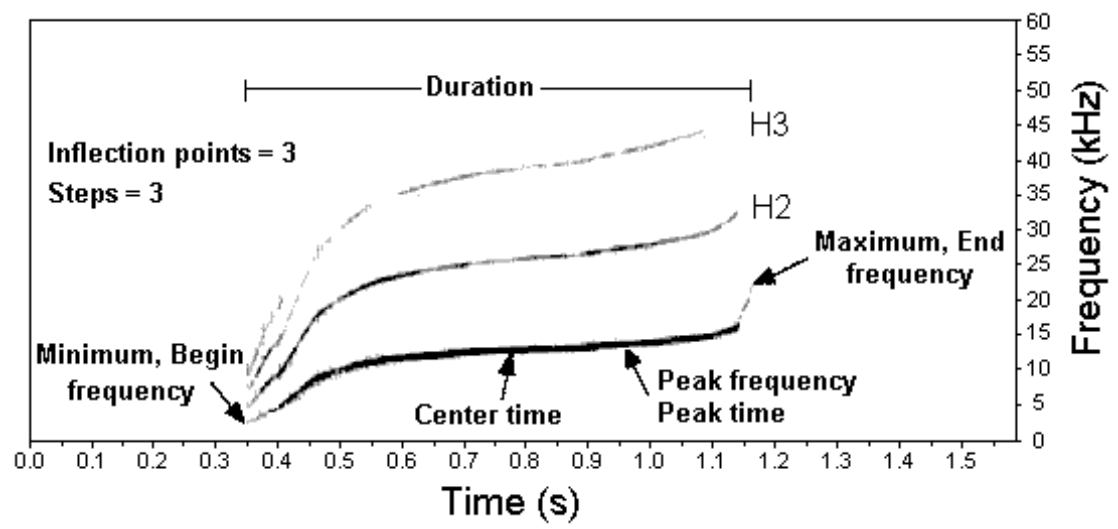

Fig. 1 - Spinner Dolphin whistle showing the fundamental frequency or whistle contour and two harmonics ( $\mathrm{H} 2$ and $\mathrm{H} 3)$. The 10 whistle parameters extracted are also shown.

usually below $20 \mathrm{kHz}$ and harmonics up to $100 \mathrm{kHz}$ (Lammers et al. 2003), and durations between 0.05 and $3.2 \mathrm{~s}$ (Wang et al. 1995a, Bazúa-Durán and Au 2002). Whistles are considered signals used to regulate group organization and function (Norris et al. 1994, Janik and Slater 1998).

The study of dolphin whistles has included the categorization of whistle contours into classes (e.g. Janik 1999, Bazúa-Durán and Au 2002) and the extraction of acoustic parameters from each whistle contour (e.g. Wang et al. 1995a, Bazúa Durán 2001). When comparing different categorization methods it has been shown that there are discrepancies in the methods (Janik 1999, Bazúa-Durán and $\mathrm{Au}$ 2002), therefore, the use of an external validation is crucial. It is not known how the categorization method compares to the extraction of acoustic parameters. In this study, the categorization of whistle contours in six classes was compared to the extraction of acoustic parameters from each whistle contour by looking at geographic variations in the whistles of Spinner and Bottlenose Dolphins.

\section{MATERIALS AND METHODS}

Bottlenose Dolphins were recorded in the Gulf of Mexico from coastal locations in Galveston and Corpus Christi Bays and Lagunas Madre and Tér- minos from 1991 to 1996, whereas Spinner Dolphin whistles were recorded from 1998 to 2000 from coastal locations in the Pacific Ocean: Midway Atoll (Northwestern Hawaiian Islands), the island of Oahu (main Hawaiian Islands), and Moorea (French Polynesia).

Bottlenose Dolphin recordings were made using a spherical hydrophone and an analog portable Marantz recorder (frequency response of the recording system was flat to $15 \mathrm{kHz}$ ), a system that can record the complete fundamental frequency of approximately $90 \%$ of Bottlenose Dolphin whistles. Spinner Dolphin recordings were made using a spherical hydrophone and a portable DAT recorder (frequency response of the recording system was flat to $24 \mathrm{kHz}$ ), a system that can record the complete fundamental frequency of $98 \%$ of Spinner whistles (Bazúa-Durán and Au 2002). The Canary@ software 1.2.4 was used to generate the spectrogram of each whistle and to extract 10 whistle parameters: beginning, ending, peak, maximum, and minimum frequencies, peak and center times, duration, and number of turns and steps (Fig. 1). These parameters were used in a Discriminant Function Analysis (DFA) to evaluate differences. Canonical correlation was also calculated to obtain the relative degree of distances between groups. The Mahalanobis distance $\left(D^{2}\right)$ between each pair of areas was used 


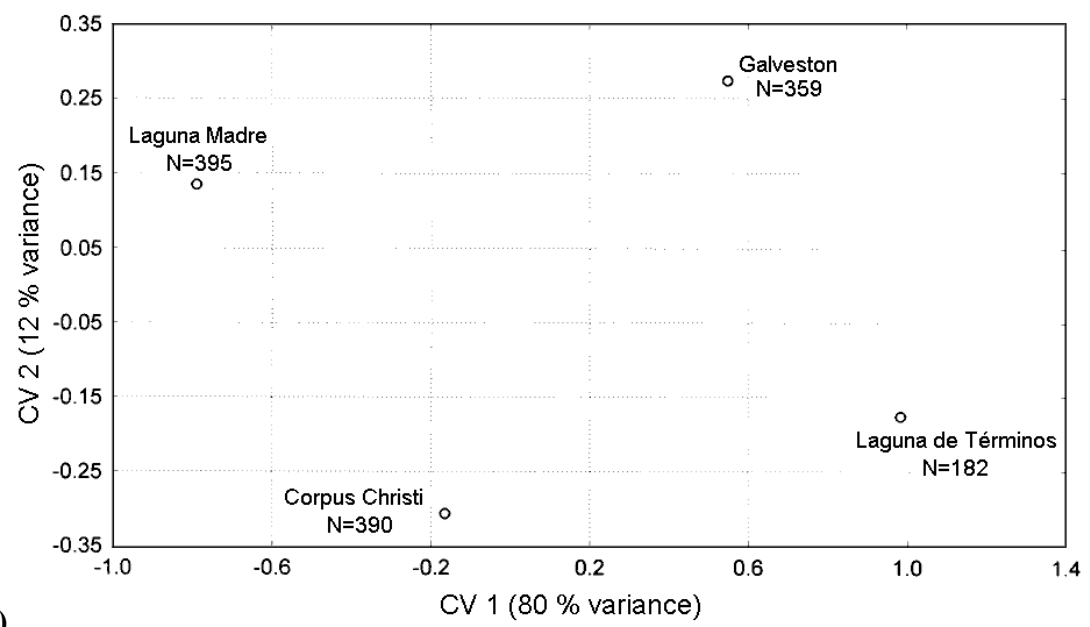

(a)

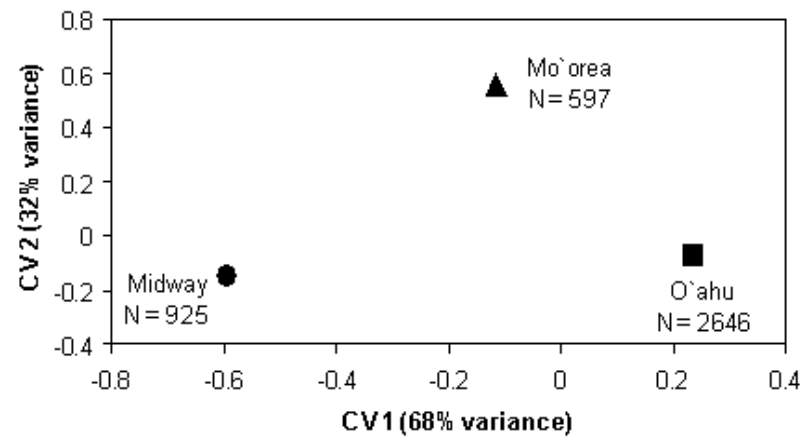

Fig. 2 - Means of the canonical variates (CV) for the between-group pairwise comparison of (a) Bottlenose and (b) Spinner Dolphin whistles. For the comparison of Bottlenose Dolphin whistles, only the first $2 \mathrm{CV}$ were plotted.

to evaluate the differences in the whistles of several areas. The larger the $\mathrm{D}^{2}$ value the more different the groups were. Each whistle contour was also ascribed to one of six categories: upsweep, downsweep, concave, convex, constant frequency, and sine (Bazúa Durán 1997, Bazúa-Durán and Au 2002). The occurrence of whistles in each category was compared between areas using chi-squared tests $\left(X^{2}\right)$. The larger the $X^{2}$ value the greater the difference between groups. Whistles used represent the different whistle contour types and their usage.

\section{RESULTS AND DISCUSSION}

A total of 1226 Bottlenose Dolphin whistles: 359 from Galveston Bay, 390 from Corpus Christi Bay, 395 from Laguna Madre and 182 from Laguna de
Términos, and of 4168 Spinner whistles: 925 from Midway, 2646 from Oahu and 597 from Moorea. were selected for analysis.

Bottlenose whistles were described in the same way when comparing whistle contour distributions in each of the six categories and whistle frequency and time parameters using Discriminant Function Analysis (Tables Ia, IIa). Along the Texas coast, Galveston was closer to Corpus Christi than to Laguna Madre, whereas Corpus Christi was closest to Laguna Madre (Fig. 2a, Table Ia). These differences found in the whistles of Bottlenose Dolphins agree with the degree of movement of animals between areas. There is more mixing between Corpus Christi and Laguna Madre than between Galveston and Corpus Christi (B. Würsig pers. comm.). Galve- 
TABLE I

Mahalanobis distances $\left(\mathrm{D}^{2}\right)$ and chi-squared values $\left(X^{2}\right)$ for the between-group pairwise comparison of (a) Bottlenose and (b) Spinner Dolphin whistles. $X_{0.995}^{2}=$ 16.75 with d.f. $=5$. Localities: a) $\mathrm{G}=$ Galveston, $\mathrm{CC}=$ Corpus Christi, $\mathrm{LM}=$ Laguna Madre, $\mathbf{L T}=$ Laguna Términos; b) $\mathrm{M}=$ Midway, $\mathrm{O}=$ Oahu, Mo = Moorea.

\begin{tabular}{|c|c|c|c|c|c|c|c|c|}
\hline \multirow[t]{8}{*}{ a) } & $\mathrm{D}^{2}$ & G & $\mathrm{CC}$ & LM & \multirow[t]{8}{*}{ b) } & $\mathrm{D}^{2}$ & $\mathrm{M}$ & $\mathrm{O}$ \\
\hline & $\mathrm{CC}$ & 0.850 & - & & & $\mathrm{O}$ & 0.693 & - \\
\hline & LM & 1.910 & 0.687 & - & & Mo & 0.736 & 0.520 \\
\hline & LT & 0.684 & 1.637 & 3.299 & & & & \\
\hline & $X^{2}$ & & & & & $X^{2}$ & & \\
\hline & $\mathrm{CC}$ & 72.01 & - & & & $\mathrm{O}$ & 106.51 & - \\
\hline & LM & 115.56 & 36.49 & - & & Mo & 194.11 & 138.96 \\
\hline & LT & 19.27 & 48.31 & 79.90 & & & & \\
\hline
\end{tabular}

TABLE II

Chi-squared values $\left(X^{2}\right)$ for the between-group comparison of (a) Bottlenose and (b) Spinner Dolphin whistles.

\begin{tabular}{|c|c|c|c|c|c|}
\hline \multirow[t]{8}{*}{ a) } & & $X^{2}$ & \multirow[t]{8}{*}{ b) } & & $X^{2}$ \\
\hline & Galveston & 63.88 & & Midway & 78.92 \\
\hline & Corpus Christi & 25.96 & & Oahu & 27.59 \\
\hline & Laguna Madre & 59.49 & & Moorea & 227.58 \\
\hline & \multirow[t]{2}{*}{ Lag. Términos } & 30.60 & & & 334.09 \\
\hline & & 179.93 & & $X_{0.95}^{2}$ & 18.31 \\
\hline & $X_{0.95}^{2}$ & 25.00 & & d.f. & 10 \\
\hline & d.f. & 15 & & & \\
\hline
\end{tabular}

ston and Laguna de Términos were the most similar areas (Fig. 2a, Table Ia), showing that mixing is not the only factor to be considered when looking at geographic variations in the whistles of dolphins using the two methods of this study.

For Spinner Dolphin whistles, each method described whistles differently. When comparing whistle frequency and time parameters using Discriminant Function Analysis Midway was found to be the most different area, while in the comparison of whistle contour distributions for each of the six categories Moorea was found to be the most different one (Fig. 2b, Table Ib, IIb).

Several factors may explain the differences found in describing the whistles of the two different dolphin species studied, and can be divided into ecological and acoustical reasons. Ecological reasons may include: (1) differences in the openness of dolphin societies for these two species, (2) differences in the average size of dolphin groups for these two species, and (3) differences in the regions inhabited by these two species.

Spinner Dolphin groups have greater fluidity when compared to Bottlenose groups; Spinners live in more open fission-fusion societies (Norris et al. 1994). Spinner groups are generally larger than Bottlenose groups in both coastal and oceanic waters (Jefferson et al. 1993, Scott and Cattanach 


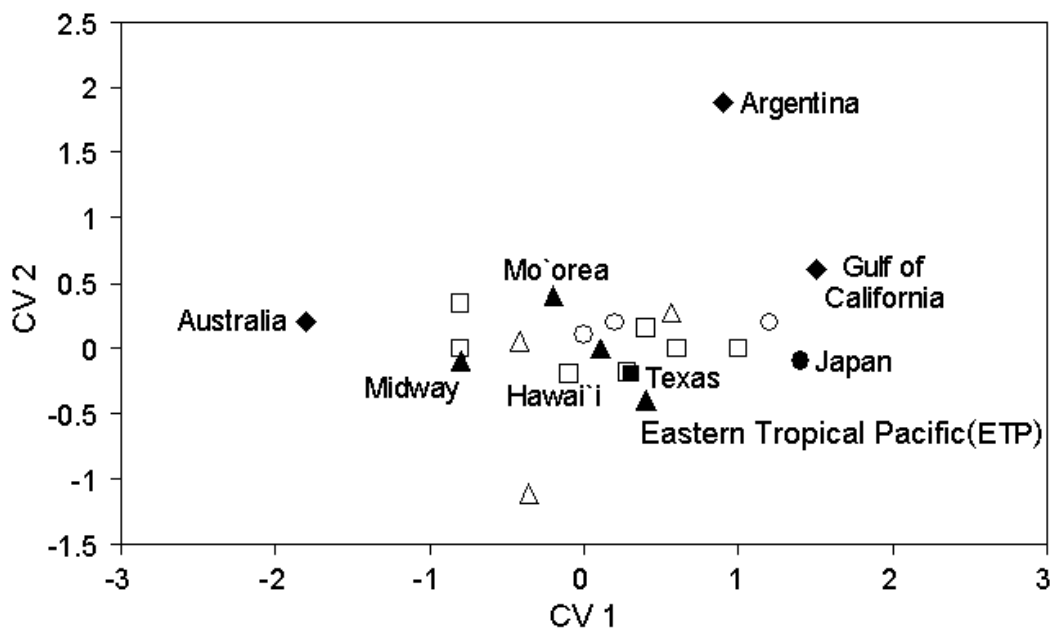

n Bottlenose dolphin macrovariations [Wang et al. (1995a)]

$\square$ Bottlenose dolphin microvariations [ $\square$ Wang et al.(1995b), Bazúa Durán(1997)

o Morisaka et al. (2003)]

A Spinner dolphin macrovariations [Bazúa-Durán et al. (2003)]

$\triangle$ Spinner dolphin microvariations [Bazúa Durán(2001)]

Fig. 3 - Means of the first 2 canonical variates (CV) for the between-group pairwise comparison of Bottlenose and Spinner Dolphin whistles looking at microgeographic and macrogeographic variations.

1998) and Spinner Dolphins are mainly pelagic whereas Bottlenose Dolphins are mainly neritic (Jefferson et al. 1993).

Acoustical reasons may include: (1) differences in the criteria used to define whistle contour categories in the studies of these two species, (2) differences in the magnitude of the geographic variations in the whistles of these two species, and (3) differences in the relationship between the average beginning and ending frequencies of the whistles from these two species.

There may be variations due to the classification limits used in the studies of both species. Spinner Dolphin whistle classification had stricter limits to define whistle contour categories than Bottlenose Dolphin whistle classification. Bottlenose Dolphin whistles will be reclassified using the stricter limits of the Spinner Dolphin whistle classification to determine the influence of stricter classification limits. In addition, there may also be measurement bias by the observer (Bazúa-Durán and Au 2002), which has not been quantified.

Microgeographic variations in the whistles of Bottlenose Dolphins (MiGV, i.e. among areas in which animals have the possibility of intermixing) were larger than macrogeographic variations in Spinner Dolphin whistles (MaGV, i.e. between areas separated by large distances) (Fig. 3). Mahalanobis distances were larger (Table I) and the means of canonical variate 1 were more separated (Figs. 2 and 3) for Bottlenose MaGV than for Spinner Dolphin MiGV.

There is an average beginning frequency $(\mathrm{BF})$ $16 \%$ lower than the average ending frequency (EF) (0.84 BF $=$ EF relationship) in Spinner Dolphin whistles (Bazúa-Durán and Au 2002) compared to a varied relationship for Bottlenose Dolphin whistles (Bazúa Durán 1997). Spinner Dolphins produce mainly upsweep whistles (47\%) (Bazúa-Durán and $\mathrm{Au} 2002$ ), whereas the whistle contour produced 
most often by Bottlenose Dolphins varies with location (Bazúa Durán 1997, Janik 2003).

\section{CONCLUDING HYPOTHESES}

It is possible that the differences found in the two methods used in this study to describe geographic variations in the whistles of two different species of dolphins are because dolphin species that differ considerably in their ecology will have larger differences in the characteristics and use of their whistles. If this is true, it is possible that species such as the pantropical Spotted Dolphin Stenella attenuata, the Clymene Dolphin Stenella clymene, the Tucuxi Sotalia fluviatilis, the Common Dolphin Delphinus delphis, and the White-beaked Dolphin Lagenorhynchus albirostris will have a similar whistle system to that of Spinner Dolphins. Likewise, species such as the Pilot Whale Globicephala macrorhynchus, the Fraser's Dolphin Lagenodelphis hosei, the Striped Dolphin Stenella coeruleoalba, and the Atlantic Spotted Dolphin Stenella frontalis will have a similar whistle system to that of Bottlenose Dolphins.

Additionally, the results of this study suggest that geographic differences may not occur solely due to geographic isolation. Other factors, such as differences in the fluidity of Spinner Dolphin groups (population structure characteristics) may be more important when looking at geographic differences in the whistles of dolphins.

\section{ACKNOWLEDGMENTS}

Project sponsored by ICMyL-UNAM, Animal Behaviour Society Developing Nations Grant, Leonida Memorial Scholarship, University of Hawaii Seed Money Grant, and University of Hawaii Foundation Grant. CBD had Fulbright-Garca RoblesCONACyT, DGAPA-UNAM, and DGIA-UNAM fellowships. Oceanic Society, Marc Lammers, Joe Mobley, Michael Poole, Whitlow Au, the volunteers in Hawaii, Alberto Delgado, Joel Ortega, Bernd Würsig, personnel at Estación del Carmen-ICMyL, Felipe Vázquez, William Evans, and Jeffrey Norris provided help during data collection. Daniel Blaine and Leticia Gracia helped with the statistical analysis.

\section{RESUMO}

Vários métodos foram usados para comparar assobios produzidos por golfinhos. Os dois métodos usados no presente estudo são: (1) uma classificação dos contornos do assobio em seis categorias (freqüência constante, modulação ascendente, modulação descendente, côncavo, convexo e senóide) e (2) a extração dos parâmetros de freqüência e tempo de cada contorno de assobio. Os assobios do Golfinho-nariz-de-garrafa ou Golfinho-flíper Tursiops truncatus são definidos da mesma maneira quando se compara, por análise de função discriminatória, a distribuição dos contornos de assobios nas seis categorias e os parâmetros tonais e temporais dos assobios. Os assobios do Golfinho-saltador Stenella longirostris são caracterizados de maneira diferente por cada método. Vários fatos podem explicar essas diferenças na classificação dos assobios de golfinhos, tais como a maior fluidez dos grupos do Golfinho-saltador em comparação aos grupos do Golfinho-nariz-de-garrafa, uma variação geográfica mais ampla dos assobios nessa última espécie de que na primeira, uma frequiência inicial média $16 \%$ mais baixa de que a freqüência final média nos assobios do Golfinhosaltador contra diferenças variadas no Golfinho-nariz-degarrafa, e o uso de critérios mais estritos para definir as categorias de contornos de assobios no Golfinho-saltador do que os usados no Golfinho-nariz-de-garrafa.

Palavras-chave: características de assobio, métodos de classificação, comparação entre assobios, variações geográficas, Delphinidae.

\section{REFERENCES}

Bazúa Durán MC. 1997. Comparisons of whistles among different populations of dolphins (Tursiops truncatus) from the Gulf of Mexico. Unpubl. Master's thesis, Universidad Nacional Autónoma de México, Mexico, DF, Mexico. 262 pp.

Bazúa Durán MC. 2001. The whistles of Hawaiian Spinner Dolphins (Stenella longirostris): description and geographic variations. Unpubl. Doctoral Diss., University of Hawaii at Manoa, Honolulu, USA. $393 \mathrm{p}$.

BAZÚA-Durán C AND AU WWL. 2002. The whistles of 
Hawaiian Spinner Dolphins. J Acoust Soc Am 112: 3064-3072.

Bazúa-Durán C, Au WWL and Oswald JN. 2003. Possible reasons for the geographic variations in the whistles of Spinner Dolphins (Stenella longirostris) of the Pacific Ocean. Abstr. 17 $7^{\text {th }}$ Conf. European Cetacean Soc. 9-13 March 2003. Las Palmas de Gran Canaria, Spain. p. 40.

DREHER JJ. 1961. Linguistic aspects of porpoise sounds. J Acoust Soc Am 33: 1799-1800.

Herman LM and Tavolga WN. 1980. The communication system of cetaceans. In: Herman LM (Ed), Cetacean behavior: mechanisms and functions. New York: Wiley and sons, p. 149-209.

JANIK VM. 1999. Pitfalls in the categorization of behaviour: A comparison of dolphin whistles classification methods. Anim Behav 57: 133-143.

JANIK VM. 2003. Geographic differences in inter-type variability of Bottlenose Dolphin whistles. Abstr. $17^{\text {th }}$ Conf. European Cetacean Soc. 9-13 March 2003. Las Palmas de Gran Canaria, Spain. p. 33.

Janik VM AND Slater PJB. 1998. Context-specific use suggests that Bottlenose Dolphin signature whistles are cohesion calls. Anim Behav 56: 829-838.

JefFerson TA, Leatherwood S AND WebBer MA. 1993. Marine mammals of the world. Roma, Italy: United Nations Environmental Program, FAO. 320 p.
Lammers MO, Au WWL and Herzing DL. 2003. The broadband social acoustic signaling behavior of Spinner and Spotted Dolphins. J Acoust Soc Am 114: 1629-1639.

Morisaka T, Shinohara M, Nakahara F AND AKaMATSU T. 2003. Geographical variations in the whistles of Indo-Pacific Bottlenose Dolphin populations. Proc. $1^{\text {st }}$ Intern. Conf. Acoustic Comm. Anim. 27-30 July 2003. College Park, Maryland, USA. p. $167-168$

Norris KS, WÜrsig B, Wells RS AND WÜrSIg M. 1994. The Hawaiian Spinner Dolphin. Berkeley and Los Angeles, CA, USA: Univ. California Press. 408 p.

Scott MD and Cattanach KL. 1998. Diel patterns in aggregations of pelagic dolphins and tunas in the eastern Pacific. Mar Mamm Sci 14: 401-428.

Wang D, Würsig B and Evans W. 1995a. Comparisons of whistles among seven odontocete species. In: Kastelein RA, Thomas JA AND Nachtigall PE. (Eds), Sensory Systems of Aquatic Mammals. Woerden, The Netherlands: De Spil, p. 299-323.

Wang D, Würsig B and Evans W. 1995b. Whistles of Bottlenose Dolphins: comparisons among populations. Aquat Mamm 21: 65-77.

Wells RS AND Scott MD. 2002. Bottlenose Dolphins. In: Perrin WF, Würsig B ANd Thewissen JGM. (Eds), The Encyclopedia of Marine Mammals. New York: Academic Press, p. 122-128. 